\title{
THE ROLE OF INTERNET MEDIA IN INFORMATIONAL COUNTERACTING BETWEEN UKRAINE AND RUSSIA DURING THE WAR IN THE EAST
}

\author{
Associate Professor Nadia Herasymchuk, \\ Ph.D, Chair of Journalism History, Institute of Journalism, Taras Shechenko National Taras \\ Shevchenko University, \\ Ukraine, Kyiv \\ Associate Professor Anatolii Yakovets, \\ Ph.D, Chair of International Media Communication and Communicative Technologies, Institute of \\ International Relations, \\ Taras Shevchenko National University, \\ Ukraine, Kyiv
}

DOI: https://doi.org/10.31435/rsglobal_ijitss/30092019/6675

\section{ARTICLE INFO \\ Received 26 July 2019 \\ Accepted 20 September 2019 \\ Published 30 September 2019 \\ KEYWORDS \\ online media, information field, information security, information war, information counter, psychological operations, information- psychological weapons, media aggression.}

\begin{abstract}
The article deals with the analysis of the role of online-media in political communication. It's shown that we are living in time of such concepts as "information war", "psychological operations", "information-psychological weapons", "media aggression". Therefore information security reflects not only the close relationship between media and conflict situations. The author focuses on information aspect of the conflict and says that it is also important as direct military action. There are also described the stages of the Russian Federation information war against Ukraine, using of anti-Ukraine methods of the information influence and ways of protection of Ukrainian information sphere in the article.
\end{abstract}

Citation: Nadia Herasymchuk, Anatoli Yakovets. (2019) The Role of Internet Media in Informational Counteracting Between Ukraine and Russia During the War in the East. International Journal of Innovative Technologies in Social Science. 6(18). doi: 10.31435/rsglobal_ijitss/30092019/6675

Copyright: (C) 2019 Nadia Herasymchuk, Anatoli Yakovets. This is an open-access article distributed under the terms of the Creative Commons Attribution License (CC BY). The use, distribution or reproduction in other forums is permitted, provided the original author(s) or licensor are credited and that the original publication in this journal is cited, in accordance with accepted academic practice. No use, distribution or reproduction is permitted which does not comply with these terms.

Introduction. These days, Internet media serve not only as informative, entertaining, and educational, but are the main weapon in conducting information wars. Satisfying of information needs of users can be considered as the main task of network information activity. The Internet is one of the phenomena that mediates various types of human activity, including cognitive, communicative and game activities. The network also provides one of the most significant opportunities for intensifying the development of human mental activity, although this problem requires a more fundamental research [1].

According to the head of the State Service for Special Communications and Information Protection Leonid Yevdochenko at the parliamentary hearings on the reform of the field of information and communication technologies and the development of the information space of Ukraine, the number of Internet users, estimated by independent experts at the end of 2015 was at least $58 \%$. It is also noted that 
coverage of the population of Ukraine by state programs of analogue broadcasting was $88.3 \%$, radiobroadcasting $-83.5 \%$. Incidentally, it was at that time when there was introduced the idea of creating by NATO the department of anti-Russian "information weapon". At the same time, $18.3 \%$ of Ukrainian households were covered by cable television, and $23.6 \%$ of households used digital television. The materials state that only $8.2 \%$ of Ukrainian households remained consumers of wire services [2].

Public opinion can be manipulated by Internet media. They influence making important strategic and geopolitical decisions, changy borders without using real weapons. It is not so important today to have a large army or a large territory. It is enough to own an arsenal of powerful communication channels of the mass media and use information and psychological methods competently.

In our time, the emergence of such concepts as "information warfare", "psychological operation", "information and psychological weapons", "media aggression", "information security" indicates not only the close connection of the media with conflict situations, but also that in the armed conflicts of today, the struggle in the information field is no less important than direct military action.

By their own experience, Ukraine and Ukrainians learned what such external information interference is and how powerful its power can be. Ukraine became a victim of an information war of the Russian Federation. Russian MMCs have done and been doing everything possible to complete disorientation in the situation, they distort the facts and manipulate the situation in order to influence public opinion both within their country and on the territory of Ukraine. There are a number of media and means of communication that operate at different levels for this purpose. As a conclusion, in March 2014 an annexation of the Crimea by Russia takes place, and later in May, pseudo-state entities "DNR" and "LNR" are created. Therefore, it is important to understand the basic principles, methods and strategy of conducting information wars for confronting media aggression, building an effective system of information security of Ukraine, and maximizing the isolation of the population from such threats. Ukraine appeared in whirlwind of the information warfare, so it is necessary to highlight the main mistakes that were made in order not to be in a similar situation in the future.

It is appropriate to mention the ancient Chinese military man Sun-Tzy, who first summarized the experience of information influence on the enemy. In his treatise "The Art of War," Sun-Tzu wrote: "In any war, as a rule, the best policy is to capture the state as a whole ... to win out hundreds of battles is not the peak of art. To conquer the enemy without a fight - this is the crown of art "[3].

Another well-known commucativist, Marshall McClein, once has proclaimed that in our time, economic ties and relationships are increasingly gaining the form of not goods but knowledge exchange. And means of mass communication are new "natural resources" that multiply the wealth of society [4].

Martin Libic's study are devoted to information wars. One of the forms of information warfare, he calls psychological form. The task of information warfare, according to the scientist, is the destruction of not physical strength but society [5].

According to the well-known national communicatvist Georgy Pocheptsov, information civilization does not perceive actions in the physical space, it sees the victory can exists in information and virtual spaces [6].

Consequently, information warfare is a component of an ideological struggle. Its purpose is to weaken the moral and material forces of an opponent or competitor and strengthen their own. It should be noted that all the years of our Independence were under the targeted informational influence of various channels of communication of the Russian Federation. A planned anti-Ukrainian information warfare was conducted, based on the dissemination of inaccurate, biased information about Ukraine, manipulation of the public consciousness not only of Ukrainian citizens, but also people of other states. The information and communication strategy were provided for the powerful propaganda of the war (Fedir Berezin), the incitement of national enmity and the use of religious factors affecting the change in the constitutional order of the Ukrainian state.

One can make a retrospective journey into the history of the issue of information wars. For example, in order to withstand the German information influence, the British Air Force launches the European service and increases the broadcast in the German language. The countries of the Nazi bloc carefully jammed the "harmful" for them radio transmissions to neutralize the effect.

Alongside, the Voice of America begins its broadcasting, which, after the attack of the Japanese Air Force on Pearl Harbor, mainly focused on the Asia-Pacific region.

Thus, the Second World War changed the concept of "propaganda" forever, giving it a purely negative meaning. Countries began to use the media not only for information and educational purposes, but for the influence, which later changed the borders of countries and dictated the interests of world leaders [7]. 
A well-known American researcher of the concept of "propaganda" P. Lainebarger in his book "Psychological Warfare" one of the first outlined the main features and methods of information wars.

P. Laynbarger believes that "psychological war in the broadest sense is the use of the foundations of psychology in military affairs. In turn, propaganda can be defined as organized conviction without the use of violent measures". The researcher also highlighted the main types of propaganda regarding the sources of conduct:

White propaganda is conducted on behalf of an official source, usually on behalf of the government or one of its bodies, including the military command of various instances. This type of propaganda is directly related to the conduct of open operations of psychological warfare.

Gray propaganda does not indicate a certain source.

Black propaganda hides its true source. This type of propaganda is associated with veiled operations of psychological warfare.

In addition, the following types of propaganda that appeared after the Second World War could be pointed out:

Conversion propaganda is a massive propaganda impact on the value orientation of a person or a group of people in order to change the basic attitudes, relations, judgments and views on the policies pursued by the authorities.

Separatist propaganda is a propaganda influence aimed at stirring up inter-group contradictions on the basis of religious, national, and social character in order to weaken unity up to the complete split of the group.

Demoralizing propaganda is a propaganda effect that aims to weaken the human psyche, to strengthen its self-preservation instincts in order to reduce morale and combat qualities to a complete refusal to engage in hostilities.

Captivity propaganda is intent to the formation of positive attitudes towards captivity as the only rational and safe way out of the situation [8].

It is an interesting fact that NATO's current term, namely "information operations", can be used in the absence of a hint of war hostilities, for example, during peacekeeping operations in order to change sentiment in society.

Thus, the short historic overview of the creation and development of "information wars", which was briefly outlined above, has shown that it is extremely important to pay attention to information resistance in order to conduct effective military confrontation and protect its territory from an external enemy. Anyway, in peace or at war, one must be prepared for a possible propaganda aggression. In a reliably informationally protected country there is a greater chance of not becoming a victim of territorial, political or ideological influence from the outside.

Now let's take a closer look at the concept of "information war", the essence, the difference from other similar terms and the role of media in it.

The term "information war" is used today quite widely, but there is no definite definition of this concept yet.

The information war today is interpreted as:

- integrated joint use of forces and means of information and armed struggle;

- communicative technology of influence on the information and information systems of the enemy while protecting their own information and their information systems;

- communicative technologies of influence on the mass consciousness;

- confrontation between states in the informational space in order to harm informational systems, processes and resources (info-technical war), undermining of political and social systems, as well as massive psychological brainwashing of troops and citizens in order to destabilize society and a country (info- psychological war) [9].

Research results. As we see, the above definitions indicate that the term "information war" is used in two semantic variants: humanitarian and technical. In the humanitarian sense, "information war" is understood as one or the other method of transformation of the informational space. In this case, we are talking about attacks on the structure of the generation of information, the imposition of a model of the world, which is intended to provide the desired types of behaviour. In the technical - as the purposeful actions, taken to achieve information advantage by harming the information, informational processes and systems of the enemy, while protecting their own information, information processes and systems. It is clear that the objects of defeat in "information wars" will be, in the fist place, the psyche and people's consciousness and in the second - the information infrastructure. Thus, one term - information war - refers to the processes, but their means and methods 
of implementation are fundamentally different: the computer virus can not affect human health, and the state of social consciousness and dominant in society.

Regarding to the means, methods and principles of traditional warfare and the war of information, they are completely different. Information weapon, as it is, do not exist at all. All that specialists call as information weapon (mass media, electronic media, linguistic means) is in fact a certain type of information communication of elements of a social structure or means of their regulation, which can lead to both constructive and destructive consequences on the object of influence. Therefore, there is the only one winner in the information war. It is the one who is able to provide more effective protection of his space from the invasion of inadequate and false information. Many countries of the world do this - they create systems for protection against information aggression. In France, for example, television is allowed to show no more than 50\% of foreign films, the absolute majority of which, as known, American [10]. G. Pocheptsov noted that the information war as a "litmus test" is capable of checking the national information space on the ability to function not only in a favorable but also in aggressive mode, when not only the time gap, but also the shortage of material and intellectual resources begins to play a special role.

Today, information wars go to the forefront of possible domination options in the information sphere. In this case, it is necessary to distinguish between two areas of information warfare: directly informational and psychological. In the first case, the object of influence is computers and information systems, in the second - the mass consciousness. Accordingly, depending on this, the modes of influence are chosen.

At the conceptual level, it can be said that countries seek to acquire information that ensures the fulfillment of their goals. Knowledge about the information that the enemy has, is a means that allows you to strengthen your power and reduce the power of your enemy [11].

Nevertheless, modern means of performing information functions made the information vulnerable to direct access and manipulation of it. Modern media technologies allow an opponent to change or create information without first obtaining facts and interpreting them. Here is a short list of characteristics of modern information systems, which leads to the appearance of such vulnerabilities: concentrated information storage, access speed, the great ability of information systems to perform their functions autonomously.

There are three main information warfare aims:

$\checkmark$ to control the informational space, using it for its own purposes, while protecting the military information functions from hostile actions (contrinformation).

$\checkmark$ use control of information to carry out information attacks on the enemy.

$\checkmark$ to increase the overall effectiveness of the armed forces through the widespread use of military information functions [12].

Carrying on a psychological war, the processes of forming public opinion are taking first place. In this case, the effect of reducing the significance of a particular event, preventing it from entering the informational space, using the "spiral of silence" in the course of a communicative campaign, in other words accepting the opinion of minority as the opinion of the majority of the population influences effectively.

Today, the term "hybrid war" is gaining in popularity. It is a question of the combined use of MMC and armed forces by the country aggressor. In fact, in the first stage there is an "information war" aimed at completely disorienting the people, giving in to their own side. At the next stage, already on the prepared infobackground, there is a physical aggression that ends with the occupation of the desired territory.

According to the US Marine Corps Lieutenant Colonel of Bill Nemeth, the hybrid war is a "modern version of guerrilla war" which "combines the latest technology and modern methods of mobilization"

In the editorial preface of the Military Balance 2015 guide, the "hybrid warfare" is interpreted as "the use of military and non-military tools in an integrated campaign aimed at achieving sudden, seizing the initiative and obtaining the psychological benefits. They used: diplomatic opportunities; large-scale and rapid informational, electronic and cyber-attacks; cover and concealment of military and intelligence operations; in combination with economic pressure ".

Developing a tactical plan in this case, the following information should be taken into account:

$\checkmark$ definition of the target audience in a given society;

$\checkmark$ beliefs, relationships, thoughts and motivation of target audiences;

$\checkmark$ analysis of vulnerability points in this behavioural model;

$\checkmark$ determining the most effective channels for achieving the goal; 
$\checkmark$ secondary study of the effect of the first stage of information warfare [13].

Thus, the "information war" is a kind of confrontation of social systems, during which physical destruction of elements of the infrastructure of opponent systems is assumed (supposed), and the main means of conducting it are informational technologies.

Indeed, the human environment has changed dramatically with the advent of the Internet information is spreading instantly around the world. Reprogramming a person has become faster, cheaper and easier than killing. Information tools are sometimes even provided free of charge, like computers to universities, to provide their users with relevant information.

The globalization of information processes and the comprehensiveness of information flows, the rapid development and increase in the volume of influence of audiences of telecommunication networks marked the end of the XX century. These factors gave reasons to the scientists (futurologists, sociologists, philosophers) to argue that the industrial society, where production played a leading role, and the intermediate post-industrial stage (for the post-Soviet space, the more acceptable term "deindustrialization") replaced the industrial society. In addition to production, the service sphere plays an important role here and a new information society comes, where the sphere of mass communications is a priority.

Already, information technology has become the most powerful productive force. For example, today $90 \%$ of the capital goes from owner to owner through electronic communications, and the potential of some information corporations is greater than of individual states. The Microsoft company, with its capital of about $\$ 700$ billion, is a striking example of the economic performance is ahead of the entire country, let's say, Spain.

German philosopher Spengler at the beginning of the 20th century foresaw an unprecedented increase in the role of information in the life of society. In the "The Decline of the West," he wrote: "In the near future, three or four world newspapers will direct the opinions of provincial newspapers and, with their help,"the will of the people" Everything will be decided by a small number of people who control these newspapers, whose names may not even be known, but the huge mass of secondrate politicians, rhetoric and tribunemen, deputies and journalists, representatives of the provincial horizons, will support the illusion of national self-determination in the lower layers of society" [14].

It should be noted that O. Spengler at that time did not anticipate the development of electronic media. If it was so, then his predictions, probably, would be even more bolder. After all, the development of telecommunications is the key factor in the information society. The amount of time it takes and the meaning of watching TV shows allow us to suggest that the TV is the main icon of our time for the average European [15].

The communication sphere in general and the media in particular - have always been active participants in armed conflicts.

Indeed, an effective information warfare is possible only with absolute control over the MMC. No wonder that the largest and most influential countries in the world use the media for their own purposes - from internal to external propaganda, ending with territorial claims, or moreover, by appropriating or separating state lands.

In our time, MMC plays an increasingly important role both in the solution of armed conflicts and in their pursuit. "Today, in developed countries, any action is impossible without proper information preparation. Wars must look fair, the enemy - the most violent, their own warriors - true heroes". Modern wars are, above all, armed political demonstrations.

In the scientific article "All Lie. The Conflict in Ukraine and the Transformation of Russian Media " by Jill Doherty, a former CNN journalist, published by the Center - 232 - A collection of scientific works. Whip Shorenstein on Media, Politics and Public Policy at the University of Harvard, 2 (15), 2015, analyzes what processes have been taking place in Russian media and media in recent years and how the basis of current Russian propaganda has been formed. She notes that today Russian propaganda uses traditional methods - misinformation, half-truths and labeling, as well as a huge amount of modern information weapons, including electronic media, digital communications, blogs and social networks.

By the way, according to estimates of the expert on information security group Vyacheslav Gusarov, the Russian Federation spends annually on the information war against Ukraine at least 3.5 billion dollars.

Recently G. Pocheptsov declared that information wars were won long before their beginning [16]. And he is right. A country with a powerful system of independent media, an information policy program, and cultural development never loses information warfare or hybrid warfare.

Conclusions. After analyzing the definition of "information war" and defining the role of the media in it, it can be concluded that information has long ceased to be an instrument or ancillary means. Today, the information and entertainment role of the media has fallen into the background. The 
greats of this world use of the Media and communications on a much wider scale. Information in "right hands" can change traditional political, economic and military spheres. Information has become an independent sphere of influence. No wonder, even a separate concept of "fourth power" appeared as the influence of journalistic activity and information on society. Today, the fourth power is in line with the executive, legislative and judicial authorities.

Therefore, it is not surprising that, against the background of such a rapid development of media influence, new forms of wars and confrontations arise. It is important to say that they have a much greater influence than physical confrontation. When the main target of the attack is human conscious and subconscious, it is impossible to objectively assess the magnitude of the impact, from which the results become unpredictable.

\section{REFERENCES}

1. Artamonova I. Audience of Internet media in the system of social communications / I. Artamonova // World standards of modern journalism: a collection of scientific works. - Cherkasy, 2010. - P. 239-243

2. In 2015, the number of Internet users in Ukraine was more than $58 \%$ of the population. UNIAN: http://www.unian.ua/society/1254409-u-2015-rotsi-kilkist-internet-koristuvachiv-v-ukrajini-stanovilo-ponad-58.html

3. Lipkan V. Information security of Ukraine in the conditions of European integration [Electronic resource] / V. Lip-kan, Y. Maksimenko, V. Zhelihovsky. - Access mode: http://mobile.pidruchniki.com/15800119/ politologiya/ ponyattya_zmist_zagroz_informatsiyniy_bezpetsi

4. Babenko Y. Information War - Weapons of Mass Destruction! [Electronic resource] / Y. Babenko. - Access mode: http://www.pravda.com.ua/rus/ articles/2006/04/20/4399050/

5. Libik M. What is an information war? [Electronic resource] / M. Libikis. - Access mode: http://viysko.com.ua/texnologiji-voyen/martin-libiki-shho-take-informacijna-vijna/

6. Pocheptsov G. Russia and Ukraine in comparing of their communicative-propaganda capabilities [Electronic resource] / G. Pocheptsov. - Access mode: http://osvita.mediasapiens.ua/material/33291

7. Rastorguev S.P. Information War / S.P.Rastorguev. - Moscow: Radio and Communications, 1998. - 416 pp.

8. Hirschman A.O. Deux siecles de rhethorique reactionnaire / A.O.Hirschman. - Paris: Fayard, 1992 - p. 23-29.

9. Pocheptsov G. G. Propaganda and counter-propaganda / G.G. Pocheptsov - Moscow: Center, 2004. - 256 p.

10. Lasswell H.D. Propaganda technology in the World War / H.D. Lasswell. - New York: The MIT Press, 1971. - 268 p.

11. Pocheptsov G. G. Information wars: trends and ways of development. - 2014 [Electronic resource] / G.G.Pocheptsov - Access mode: http://psyfactor.org/psyops/infowar7.htm

12. Rastorguev S.P. Information War / S.P.Rastorguev. - Moscow: Radio and Communications, 1998. - 416 pp.

13. Johnson L. S. Toward a Functional Model of Information Warfare: A Major Intelligence Challenge / L. Scott.Johnson // Studies in Intelligence. - 1997. - № 1. - p. 49-56.

14. Buzan B. From international system tointernational society: Structural realism and regime theory meet the English school / Barry Buzan // International Organisation. - 1993. - Vol.7, Issue 3. - p. 327-352.

15. Hirschman A.O. Deux siecles de rhethorique reactionnaire / A.O.Hirschman. - Paris: Fayard, 1992. - p. 23-29.

16. Georgy Pocheptsov: "Information wars are won long before they begin" - 2015 [Electronic resource] / G. Pocheptsov - Access mode: http://psyfactor.org/lect/pocheptsov11.htm 